\title{
CELL SURFACE HYDROPHOBICITY AND ADHERENCE OF A STRAIN OF GROUP B STREPTOCOCCI DURING THE POST-ANTIBIOTIC EFFECT OF PENICILLIN
}

\author{
Ângela Maria Mendes ARAúJO, Ivi Cristina Menezes de OLIVEIRA, Marcos Corrêa de MATTOS \& Leslie C. BENCHETRIT
}

\begin{abstract}
SUMMARY
The minimum inhibitory concentration and post-antibiotic effects of an antimicrobial agent are parameters to be taken into consideration when determining its dosage schedules. The in vitro post-antibiotic effects on cell surface hydrophobicity and bacterial adherence were examined in one strain of group B streptococci. Exposure of the microorganism for $2 \mathrm{~h}$ at $37{ }^{\circ} \mathrm{C}$ to $1 \mathrm{x}$ MIC of penicillin induced a PAE of $1.1 \mathrm{~h}$. The cell surface charge of the Streptococcus was altered significantly during the postantibiotic phase as shown by its ability to bind to xylene: hydrophobicity was decreased. Bacterial adherence to human buccal epithelial cells was also reduced. The results of the present investigation indicate that studies designed to determine therapeutic regimens should evaluate the clinical significance of aspects of bacterial physiology during the post-antibiotic period.
\end{abstract}

KEYWORDS: Streptococci; Post-antibiotic effect; Penicillin, Hydrophobicity; Adherence.

\section{INTRODUCTION}

Lancefield group B streptococci (GBS) have long been recognized as etiologic agents of a variety of human infections, particularly in the neonatal period where the microorganisms can be a common cause of serious diseases such as sepsis and meningitis ${ }^{3,38}$. Infections with GBS continue to occur with significant frequency in children and adults ${ }^{14,17}$. Antibiotic susceptibility testing of GBS indicates that these bacteria are sensitive to penicillin $\mathrm{G}$.

Antibiotics in inhibitory concentrations have been the subject of a great number of studies and reviews during the last decades. Among the investigations on the interaction of antimicrobial agents and microorganisms is the suppression of bacterial growth after exposure to an antibiotic for a short period of time ${ }^{11}$. Such a delay in turbidity development was observed by BIGGER $^{6}$ after the addition of penicillinase in staphylococcal and streptococcal cultures that had been previously exposed to penicillin $\mathrm{G}$ in vitro. This post-antibiotic effect (PAE) has thus been the purpose of many studies during the last decades, because of morphological, ultrastructural and biochemical changes that it produces in bacteria ${ }^{18}$. Regarding streptococci of groups A an $\mathrm{C}$ exposed to inhibitory concentrations of penicillin during growth in vitro, changes were observed in the elaboration of bacterial antigens, such as enzymes, toxins and cellular components ${ }^{2,15}$ in the cell-surface hydrophobicity and also adherence capabilities ${ }^{2,16}$.

However, some aspects of the biology of GBS during the postantibiotic phase remained to be determined. We report here the PAE of an inhibitory concentration of penicillin on the cell surface hydrophobicity of a strain of GBS as well as on bacterial adherence to human buccal cells.

\section{MATERIALS AND METHODS}

Bacterial strain: The strain no. 90356 used in this study was obtained from the Bacteriology Laboratory of the Marcílio Dias Navy Hospital (Rio de Janeiro) and had been isolated on May 1988 from the cerebrospinal fluid of a 4-day old baby and was responsible for a fatal meningitis. Culture of the child's blood also yielded growth of the streptococcus. Serological grouping was carried out with extracts prepared by the nitrous acid procedure ${ }^{12}$ and the group reaction was determined by running immunodiffusion tests in agarose slides ${ }^{5}$. The isolate was then typed by the capillary precipitin method using HCLextracts $^{5,22}$. Grouping and typing sera were prepared in rabbits using bacterial strains and protocols then kindly provided by R.R.FACKLAM (CDCs, Atlanta, USA). The typing program also received assistance from P. FERRIERI (University of Minnesota, Minneapolis, USA). The identification of the serotype was done by immunoprecipitation in agarose $^{5}$ and $\mathrm{HCl}$ - antigen extracts from $20-\mathrm{mL}$ broth cultures. The strain belonged to serotype III and was also characterized by pulsedfield electrophoresis of DNA treated with SmaI restriction enzyme as previously described ${ }^{33}$. The isolate displayed a DNA pattern with a profile named $\mathrm{G}_{2}{ }^{33,34}$. The streptococcus was sensitive to chloramphenicol, clindamycin, erythromycin, penicillin, rifampicin and vancomycin and resistant to tetracycline, as determined by the disk diffusion method ${ }^{33}$. Stock cultures were stored in the lyophilized state 


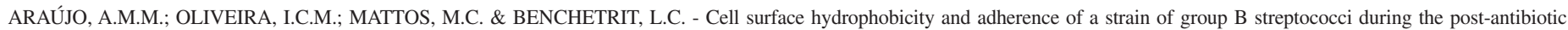
effect of penicillin. Rev. Inst. Med. trop. S. Paulo, 50(4): 203-207, 2008

in sheep blood. For use, purity of the cultures was assessed by streaking the bacteria onto $5 \%$ sheep blood agar plates.

Culture medium and determination of the minimum inhibitory concentration: Broth for bacterial growth was Todd-Hewitt (Difco Laboratories). Penicillin was obtained as reference powder with a potency of 1,594 U/mg from the Wyeth Laboratories, São Paulo, Brazil. The powder was dissolved in water and the solution was sterilized through membrane filters and added to the autoclaved media to reach the final concentrations as indicated on the same day experiments were performed. Control cultures did not contain antiobiotic. The minimal inhibitory and bactericidal concentrations of the penicillin were determined according to the National Committee for Clinical Laboratory Standards ${ }^{29}$. Penicillinase (type I; from Bacillus cereus, Sigma) was used, as indicated, at the final concentration of $20 \mathrm{U} / \mathrm{mL}$.

Determination of the post-antibiotic effect: The PAE was determined by methods described elsewhere. Three colonies of an overnight growth of streptococci on a blood plate were picked and resuspended in $2 \mathrm{~mL}$ of sterile physiological saline. After vigorous shaking, $5 \mu \mathrm{L}$ of the bacterial suspension were transferred to $5 \mathrm{~mL}$ of broth and incubated in a water bath for $18 \mathrm{~h}$ at $37{ }^{\circ} \mathrm{C}$. On the next day the culture was vigorously mixed and diluted into broth to a turbidity of 0.3 at $540 \mathrm{~nm}$ to provide the desired starting inoculum. An aliquot $(0.5 \mathrm{~mL})$ of this inoculum was diluted into $5 \mathrm{~mL}$ of broth containing 1 $\mathrm{x}$ MIC of penicillin per $\mathrm{mL}$ and incubated for $2 \mathrm{~h}$ at $37^{\circ} \mathrm{C}$ without agitation. Thereafter, the streptococci were sedimented at $500 \mathrm{~g}$ for 10 min, washed twice with $5 \mathrm{~mL}$ of saline for removal of penicillin and resuspended in antibiotic-free broth with added penicillinase. The culture was again incubated at $37{ }^{\circ} \mathrm{C}$. Bacterial growth was followed at hourly intervals by measuring the optical density $(540 \mathrm{~nm})$ and withdrawing aliquots for viable countings until the end of the logarithmic phase of growth. Control bacteria were also washed and diluted (1:10) before regrowth was allowed to proceed and optical measurements were carried out and viable counts determined. The postantibiotic effect was calculated from the equation: PAE $=\mathbf{T}-\mathbf{C}$ where $\mathbf{T}$ was the time required for the penicillin culture to increase one $\log$ $10 \mathrm{CFU}$ above the value observed after drug removal, and $\mathbf{C}$ was the time required for the count of the control streptococci to also increase by one $\log 10^{11,15,16}$. Each PAE experiment was performed in triplicate on three separate opportunities to ensure reproducibility.

Adherence assay: The methods used to examine bacterial adherence to buccal epithelial cells were previously reported ${ }^{8,15}$. Streptococci were obtained at various times during the post-antibiotic phase incubation (times: 1, 2 and $4 \mathrm{~h}$ ), washed three times in sterile phosphate buffered saline (PBS; $\mathrm{pH} 7.4$ ) resuspended in PBS to an optical density of 0.2 at $540 \mathrm{~nm}-10^{7} \mathrm{CFU} / \mathrm{mL}$ - as determined by viable counting and sonicated in a Branson B-15 P sonifier (output power, $75 \mathrm{~W}$ ) for two min to reduce chain size and disrupt clumps of cocci. Buccal cells collected from the cheek mucosa of healthy adults using sterile tongue depressors were washed with PBS and resuspended in the same buffer to a density of $10^{5}$ cells $/ \mathrm{mL}$. For adherence assays, equal volumes (one $\mathrm{mL}$ ) of bacterial and epithelial cells suspensions were mixed, incubated on a rotating support $(20 \mathrm{rpm} / \mathrm{min})$ at $37{ }^{\circ} \mathrm{C}$ for $30 \mathrm{~min}$, and centrifuged at $2,000 \mathrm{~g}$ for $15 \mathrm{~min}$. The sediments were washed with PBS for removal of non-adherent cocci, Gram-stained for microscopic examination of bacteria associated with the buccal cells and the numbers of adhering streptococci were counted in 600 epithelial cells for each time of incubation (100 cells in each slide preparation). Results were expressed as the numbers of microorganisms per buccal cell (mean values \pm standard deviations). Control epithelial cells (with no added bacteria) were included in each experiment to determine the background number of naturally adherent cocci. Student's $\mathrm{t}$ test was used for analysis of the differences in the adherence assays and $p<0.01$ was considered as statistically significant.

Measurement of the cell surface hydrophobicity: The hydrophobicity indexes of the streptococcal cellular surface after exposition to penicillin were determined according to techniques described elsewhere ${ }^{15,39}$. For this purpose, bacteria (from $50 \mathrm{~mL}$ cultures) were obtained during the post-antibiotic phase at times 1,2 and $4 \mathrm{~h}$ after removal and penicillinase inactivation of the antibiotic, washed in PBS and adjusted to an absorbancy of 0.4 at $660 \mathrm{~nm}$ (A660 control). Thereafter, their ability to adhere to xylene was determined as previously described ${ }^{4,15}$. Namely, washed streptococci $(2.5 \mathrm{~mL})$ were added to xylene $(1 \mathrm{~mL})$, vigorously agitated during two min and left on the bench for $20 \mathrm{~min}$ at room temperature to allow for separation of the two phases. The aqueous phase was removed from the bottom of the tube and its absorbancy also measured (A 660 test) against PBS. The index of hydrophobicity (HI) was calculated as follows $: \mathrm{HI}=(\mathrm{A} 660$ control - A 660 test) / A660 control. The values of HI indexes were too close to the upper limit and did not allow for an analysis by the Student's $t$ test. Therefore, they were transformed into angles ${ }^{15}$ for the statistical analysis and then the following formula was used: Value of angle = Arc. $\sin ^{-1} \sqrt{H I}$. Values of $p<0.01$ were considered statistically significant.

\section{RESULTS}

The MIC and MBC of penicillin for the streptococcus were 0.06 and $0.12 \mu \mathrm{g} / \mathrm{mL}$, respectively. The results of the PAE experiments are shown in Table 1. Penicillin at 1 x MIC exercised a significant effect on the strain. The time required for the number of viable counts to increase $1 \log 10$ above the number present immediately after completion of the procedure used for penicillin removal and inactivation was $2.5 \mathrm{~h}$. The corresponding time required by the control culture (no exposure to antibiotic) was $1.4 \mathrm{~h}$. Penicillin thus exercised a PAE of $1.1 \mathrm{~h}$ on the streptococcal strain.

Table 2 shows the difference in adherence of streptococci treated with penicillin and control microorganisms. The number of bacteria adhering was determined in a total of 4,700 buccal cells. The mean number of naturally adhering streptococci in a total of 1,100 epithelial cells was only 1.14 . The smallest value observed for untreated bacteria adhered to 1,800 buccal cells was 14.20. A decrease of GBS adherence to buccal cells occurred starting at $1 \mathrm{~h}$ incubation during the postantibiotic period compared to the control microorganisms. The mean value (8.21) slightly increased during the $4 \mathrm{~h}$ of incubation (9.58 and 9.90).

The cell surface hydrophobicity of untreated streptococci and exposed to $1 \mathrm{x}$ MIC of penicillin is also described in Table 2. As analyzed by the Student's t test, bacterial hydrophobicity was increased with significant differences between the control and exposed streptococci. At $4 \mathrm{~h}$, the two types of cultures exhibited an increased 


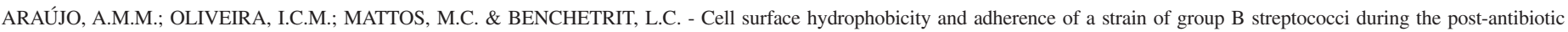
effect of penicillin. Rev. Inst. Med. trop. S. Paulo, 50(4): 203-207, 2008

Table 1

Post-antibiotic effect of 1 x MIC of penicillin on the streptococcal group B strain No. 90356 in Todd Hewitt broth ${ }^{\mathrm{a}}$

Streptococcal cultures

$\log 10 \mathrm{CFU} / \mathrm{mL}$ in the inoculum

Time of exposure to penicillin (h)

Log $10 \mathrm{CFU} / \mathrm{mL}$ of culture after washing, centrifugation and dilution

Log $10 \mathrm{CFU} / \mathrm{mL}$ of culture after removing penicillin by washing, centrifugation

and treatment with penicillinase

Time for cultures to grow $1 \log 10$ (h)

Post- antibiotic effect (h)
Viable colony counts $(\log 10 \mathrm{CFU} / \mathrm{mL})$

Added penicillin

Control values

$(1 \times \mathrm{MIC})^{\mathrm{b}}$

(no added penicillin)

$5.57 \quad 5.75$

2.0

$5.92^{\mathrm{c}}$

6.47

2.5

1.4

$1.1 \pm 0.25^{\mathrm{d}}$

a, For description of the PAE determination, see Materials and Methods; $b, 1 \times$ MIC $=0.06 \mu \mathrm{g} / \mathrm{mL}$; c, The pellet was resuspended in half the original volume of culture broth; d, PAE determinations were carried out three times on three separate opportunities; the value is given as a mean (1.1) and standard deviation is 0.25 .

Table 2

Penicillin post-antibiotic effect on the bacterial cell surface hydrophobicity of the GBS strain No. 90356 and adherence to human epithelial buccal cells ${ }^{\mathrm{a}}$

Hydrophobicity

Streptococcal cultures
Value of angles (Mean \pm SD)
Adherence

No. of assays
No. of streptococci adhering to one buccal cell (Mean \pm SD)

\section{Control culture}

$1^{\mathrm{b}}$

2

4

Added penicillin ${ }^{\mathrm{d}}$

1

2

4

$$
\begin{gathered}
11.93 \pm 12.79 \\
21.42 \pm 10.27 \\
58.45 \pm 11.23 \\
2.39 \pm 6.56 \\
2.44 \pm 7.18 \\
17.58 \pm 18.26
\end{gathered}
$$

$$
\begin{gathered}
14.42 \pm 10.09^{c} \\
16.32 \pm 13.57 \\
14.20 \pm 13.18 \\
\\
8.21 \pm 7.03 \\
9.58 \pm 9.10 \\
9.90 \pm 9.63
\end{gathered}
$$

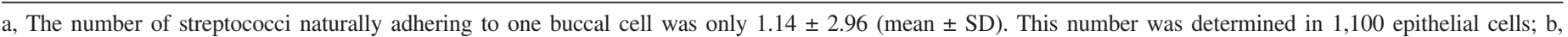

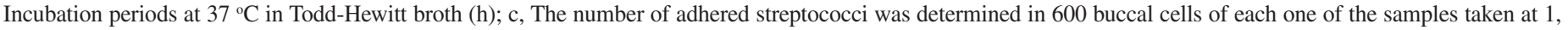
2 and $4 \mathrm{~h}$ of incubation (100 cells in each slide preparation); $\mathrm{d}, 1 \times \mathrm{MIC}=0.06 \mu \mathrm{g} / \mathrm{mL}$.

hydrophobicity although much higher for the treated streptococci $(2.39$ to $17.56 ; 635 \%)$ than for the control bacteria $(11.93$ to $58.45 ; 390 \%)$.

\section{DISCUSSION}

Since the first description of persistent suppression of bacterial growth after a short exposure of microorganisms to antibiotics ${ }^{6}$, the phenomenon has been largely reported. A number of in vitro studies have quantified the PAE induced by numerous antibiotics in a variety of Gram-positive ${ }^{10,19,20,21,23,30}$ and Gram-negative bacteria ${ }^{19,20,21,32}$.

In experiments reported in 1995 we studied the PAE of 1 x MIC of penicillin on bacterial growth of two strains of Streptococcus anginosus and also on the production of streptococcal substances such as deoxyribonuclease (DNAse), hyaluronidase (HAase) and both free and cell bound hemolysin activities ${ }^{2}$. The same year we determined the effect of $1 \mathrm{x}$ MIC of penicillin on a strain of Lancefield group A streptococcus and production of DNase and HAase as well as microbial adherence and cell surface hydrophobicity were studied during the post-antibiotic phase ${ }^{15}$. In a recent investigation we analyzed the PAE of penicillin on cellular morphology, group-specific carbohydrate and free and bound hemolysins of the same strain of group A streptococcus ${ }^{16}$. There was no report in the scientific literature about the way penicillin affects group B streptococci during the postantibiotic phase.

In the experiments described here, we treated a group B streptococcal strain with $1 \mathrm{x}$ MIC of penicillin and observed a slow bacterial recovery of antibiotic toxic effects. The PAE value of the antibiotic for the isolate was $1 \mathrm{~h}$. In our former experiments the PAE values were significantly different for other species of streptococci 3.4 and $3.5 \mathrm{~h}$ for the $S$. anginosus strains ${ }^{2}$ and $2,8 \mathrm{~h}$ for the group A streptococcus ${ }^{15,16}$. RAMADAN et al. ${ }^{35}$ reported that erythromycin and azythromycin induced PAE against group A streptococci - 2.4 and 4.3 $\mathrm{h}$ respectively - and several other studies have assessed the PAE of antimicrobials on Gram-positive cocci.

The duration of the PAE after exposure of group A streptococci to 50 times the MIC of penicillin was $3.2 \mathrm{~h}^{25}$. A PAE of $2.4 \mathrm{~h}$ was observed in the streptococci exposed for two $\mathrm{h}$ to penicillin at $10 \mathrm{x} \mathrm{MIC}^{30,31}$. A concentration of $5 \mathrm{mg} / \mathrm{mL}$ (> $10 \times \mathrm{MIC}$ ) of a streptogramin antibiotic produced a PAE of $18 \mathrm{~h}$ after exposure for $30 \mathrm{~min}^{9}$. Treatment of the streptococci with $1 \mathrm{x}$ MIC of ciprofloxacin or ofloxacin for $3 \mathrm{~h}$ resulted in PAE of 2.3 and $2.0 \mathrm{~h}$, respectively ${ }^{19,20}$. When $5 \times$ MIC of cefcanel 


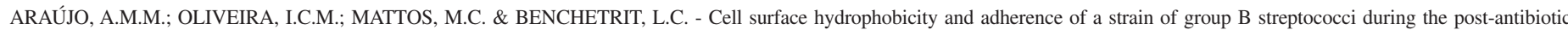
effect of penicillin. Rev. Inst. Med. trop. S. Paulo, 50(4): 203-207, 2008

was used for treating the group A streptococcus during $2 \mathrm{~h}$, a PAE of $2.3 \mathrm{~h}$ was $\operatorname{seen}^{25}$.

The cellular and molecular events involved in this phenomenon have received limited investigation. Thus, the interaction of antibiotic with the microorganism at inhibitory concentrations occurs through mechanisms not fully understood. There is the possibility that the drug binds to sites of the bacterial cell surface in quantities sufficient to produce a bacteriostatic effect as the result of reversible damages ${ }^{27}$. Regarding $\beta$-lactam antibiotics, the PAE could represent the time required for the bacteria to produce new enzymes necessary to the cell wall synthesis or for liberation of the enzymes bound to the drug $7,26,40$.

Group A streptococci adherence to human oropharyngeal tissues followed by colonization and, in some cases, invasion and dissemination can lead to streptococcal pharyngitis and sequelae like rheumatic fever. FAINSTEIN et al..$^{13}$ examined the adherence of group A streptococci to pharyngeal cells of asymptomatic individuals and of patients with acute respiratory illness. Adherence of the streptococci increased in subjects with disease of the respiratory tract and did not change during viral infection. REED et al. ${ }^{36}$ showed that pharyngeal cells from individuals with rheumatic fever bound more to rheumatic feverassociated group A strains than to rheumatic fever-unassociated streptococci. Pharyngeal cells of normal control subjects did not show such a difference in binding to rheumatic fever-associated and unassociated group A streptococci. By studying the adhesive ability of a strain of group A streptococci with human buccal epithelial cells we observed that bacterial adherence was greatly reduced during the postantibiotic phase ${ }^{15}$. The adherence capabilities of streptococci to host mucosal cells depend on the bacterial surface properties like hydrophobicity and could also be mediated by factors others than this physicochemical characteristic. Our present data indicate a marked decrease of the GBS cell-surface hydrophobicity after exposure to $1 \mathrm{x}$ MIC of penicillin. Even $3 \mathrm{~h}$ after removal and inactivation of the antibiotic, there was a significant difference between the cell-surface charge of treated and non-treated bacteria. These findings could be supported by results of a previous study that showed that trypsin-treated GBS adhered to human buccal epithelial cells in lesser numbers ${ }^{28}$. In another investigation we also observed that treatment of group A streptococci with penicillin did not influence the cell-surface hydrophobicity as the magnitude of changes in value of angles did not differ significantly ${ }^{15}$. RAMADAN et al. ${ }^{35}$ showed a decrease of the group A streptococcal cell-surface hydrophobicity during the PAE induced by azythromycin and erythromycin. The alterations could be related to mechanisms such as effects on the bacterial surface, formation of aberrant adhesins, suppression of production of surface adhesins or even absence of expression of these adhesions $s^{1,24.37,41}$.

The present study was performed with only one strain of one bacterial species. Further studies need to be carried out to determine the clinical implications of the alterations brought about by inhibitory amounts of penicillin during the post-antibiotic phase, especially biochemical and molecular events that can affect the biology of GBS and could thus explain the strain variability observed in cell-surface structure and hydrophobicity, cell-surface components and antigens, and liberation of enzymes and toxins. As far as susceptibility to antibiotics is concerned, bacteria grown in vivo may differ significantly from microorganisms cultivated in vitro. The activity of the antibiotic against the bacteria in vivo is greatly influenced by immunological defense mechanisms and pharmacokinetic conditions. Therefore, therapeutic regimens designed for treating the infected host should include studies of the in vitro PAE of antibiotics and, obviously, in vivo trials.

\section{RESUMO}

\section{Hidrofobicidade de superfície celular e aderência de uma estirpe de estreptococos do grupo B durante o efeito pós-antibiótico da penicilina}

A concentração mínima inibitória e os efeitos pós-antibióticos (EPA) de um agente antimicrobiano são parâmetros que devem ser levados em consideração quando da determinação do esquema de dosagem. Os efeitos pós-antibióticos in vitro na hidrofobicidade de superfície celular e na aderência foram pesquisados em uma amostra de estreptococos do grupo B. A exposição do microrganismo por $2 \mathrm{~h}$ a $37{ }^{\circ} \mathrm{C}$ a 1 x CMI de penicilina induziu um EPA de $1,1 \mathrm{~h}$. A carga da superfície celular da bactéria foi alterada significativamente durante a fase pós-antibiótica revelada através da capacidade de ligação ao xileno, indicada pela diminuição da hidrofobicidade. A aderência bacteriana às células epiteliais bucais humanas também foi reduzida. Os resultados da investigação demonstram que estudos clínicos destinados a determinar regimes terapêuticos deveriam incluir o conhecimento da fisiologia bacteriana durante o período pós-antibiótico.

\section{ACKNOWLEDGMENTS}

This study was supported by grants from CNPq (Brasília), FINEP and FAPERJ (Rio de Janeiro) and The Thrasher Research Fund (Salt Lake City, USA). We thank the Wyeth Laboratories for the gift of penicillin, Dr. Kim for supplying the streptococcal group A tolerant strain and Drs. Ferrieri and Facklam for help in the typing program.

\section{REFERENCES}

1. ALKAN, M.L. \& BEACHEY, E.H. - Excretion of lipoteichoic acid by group A streptococci: influence of penicillin on excretion and loss of ability to adhere to human oral mucosal cells. J. clin. Invest., 61: 671-677, 1978.

2. AMARAL, M.M. \& BENCHETRIT, L.C. - Postantibiotic effect of penicillin on Streptococcus anginosus. Zbl. Bakt., 283: 332-339, 1995.

3. BAKER, C.J. - Group B streptococcal infections. Clin. Perinatol., 24: 59-70, 1997.

4. BATSCHELET, E. - Exponential and logarithmic functions. In: BATSCHELET, E., ed. Introduction to Mathematics for life scientists. New York, Springer-Verlag, 1973. p. $119-142$.

5. BENCHETRIT, L.C.; FRACALANZZA, S.E.L.; PEREGRINO, H.; CAMELO, A.A. \& SANCHES, L.A. - Carriage of Streptococcus agalactiae in women and neonates and distribution of serological types: a study in Brazil. J. clin. Microbiol., 15: 787$790,1992$.

6. BIGGER, J.W. - The bactericidal action of penicillin on Staphylococcus pyogenes. Irish J. med. Sci., 227: 553-568, 1944.

7. BUNDTZEN, R.W.; GERBER, A.U.; COHN, D.L. \& CRAIG, W.A. - Postantibiotic suppression of bacterial growth. Rev. infect. Dis., 3: 28-37, 1981.

8. CAPARON, M.G.; STEPHENS, D.S.; OLSEN, A. \& SCOTT, J.R. - Role of M protein in adherence of group A streptococci. Infect. Immun., 59: 1811-1817, 1991. 


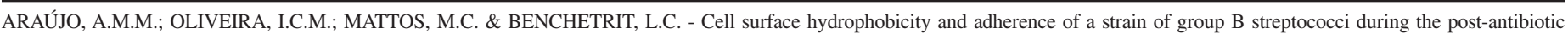
effect of penicillin. Rev. Inst. Med. trop. S. Paulo, 50(4): 203-207, 2008

9. CHIN, N.X. \& NEU, H.C - Post-antibiotic effect of the new streptogramin RP59500. Europ. J. clin. Microbiol. infect. Dis., 11: 642-645, 1992.

10. COYLE, E.A.; CHA, R. \& RYBAK, M.J. - Influences of linezolid, penicillin, and clindamycin, alone and in combination, on streptococcal pyrogenic exotoxin A release. Antimicrob. Agents Chemother., 47: 1752-1755, 2003.

11. CRAIG, W.A \& GUDMUNDSSON, S. - The postantibiotic effect. In: LORIAN, V. ed. Antibiotics in laboratory Medicine. 3. ed. Baltimore, Williams \& Wilkins, 1991. p. 403-431.

12. EL KHOLY, A.; WANNAMAKER, L.W. \& KRAUSE, R.M. - Simplified extraction procedure for serological grouping of beta-hemolytic streptococci. Appl. Microbiol., 28: $836-839,1974$

13. FAINSTEIN, V.; MUSHER, D.M. \& CATE, T.R. - Bacterial adherence to pharyngeal cells during viral infection. J. infect. Dis., 141: 172-176, 1980.

14. FARLEY, M.M. - Group B streptococcal disease in nonpregnant adults. Clin. infect. Dis., 33: 556-561, 2001.

15. GARCIA, L.B.; BENCHETRIT, L.C. \& BARRUCAND, L. - Penicillin postantibiotic effects on the biology of group A streptococci. J. Antimicrob. Chemother., 5: 475482, 1995.

16. GARCIA, L.B.; FONSECA, M.E. \& BENCHETRIT, L.C. - Effect of penicillin on surface carbohydrate, hemolysin and morphology of Streptococcus pyogenes during and after the post-antibiotic phase. J. Chemother., 16: 238-243, 2004.

17. GIBBS, R.S.; SCHRANG, S. \& SCHUCHAT, A. - Perinatal infections due to group B streptococci. Obstet. Gynec., 104: 1062-1076, 2004.

18. GUAN, L. \& BURNHAM, J.C. - Postantibiotic effect of CI-960, enoxacin and ciprofloxacin on Escherichia coli: effect on morphology and haemolysin activity. J. Antimicrob. Chemother., 29: 529-538, 1992.

19. HANBERGER, H.; NILSSON, L.E.; NILSSON, M. \& MALLER, R. - Post-antibiotic effect of beta-lactam antibiotics on Gram-negative bacteria in relation to morphology, initial killing and MIC. Europ. J. clin. Microbiol. infect. Dis., 10: 927-934, 1991.

20. HOWARD; B.M.A.; PINNEY, R.J. \& SMITH, J.T. - Contributions of post-antibiotic lag and repair-recovery to the post-antibiotic effects of ciprofloxacin on Escherichia coli, Klebsiella pneumoniae, Staphylococcus aureus and Streptococcus pyogenes. Chemotherapy, 39: 22-31, 1993.

21. HOWARD, B.M.A.; PINNEY, R.J. \& SMITH, J.T. - Post-antibiotic effects of ofloxacin on Escherichia coli, Klebsiella pneumoniae, Staphylococcus aureus and Streptococcus pyogenes. Chemotherapy, 39: 265-271, 1993.

22. LANCEFIELD, R.C. - A serological differentiation of specific types of bovine haemolytic streptococci (group B). J. exp. Med., 59: 441-458, 1934.

23. LING, T.K.W.; FUNG, K.S.C. \& CHENG, A.F.B. - In vitro activity and post-antibiotic effect of quinupristin/dalfopristin (Synercid). Chemotherapy, 47: 243-249, 2001.

24. LORIAN, V. \& GEMMELL, G.G. - Effect of low antibiotic concentrations on bacteria: effects on ultrastructure, virulence, and susceptibility to immunodefenses. In: LORIAN, V. ed. Antibiotics in laboratory Medicine. Baltimore, Williams \& Wilkins, 1991. p. 493-555.

25. LÖWDIN, E.; TORNQVIST, I.O. \& CARS, O. - The postantibiotic effect of cefcanel on beta-hemolytic streptococci group A in vitro and in vivo. Scand. J. infect. Dis. Suppl., 74: 190-194, 1991.
26. MACKENZIE, F.M. \& GOULD, I.M. - The post-antibiotic effect. J. Antimicrob. Chemother., 32: 519-537, 1993.

27. Mc DONALD, P.J.; CRAIG, W.A \& KUNIN, C.M. - Persistent effect of antibiotics on Staphylococcus aureus after exposure for limited periods of time. J. infect. Dis., 135: 217-223, 1977

28. NAGAO, P.E.; SILVA-FILHO, F.C.; BENCHETRIT, L.C. \& BARRUCAND, L. - Cell surface hydrophobicity and the net electric surface charge of group B streptococci: the role played in the microorganism-host cell interaction. Microbios, 28: 207-216, 1995.

29. NATIONAL COMMITTEE FOR CLINICAL LABORATORY STANDARDS - Methods for dilution antimicrobial susceptibility tests for bacteria that grow aerobically. 3. ed. Wayne, National Committee for Clinical Laboratory Standards, 1993. (Approved standard. NCCLS document M7-A3)

30. ODENHOLT, I.; HOLM, S.E. \& CARS, O. - Effect of benzylpenicillin on Streptococcus pyogenes during the postantibiotic phase in vitro. J. Antimicrob. Chemother., 24: 147-156, 1989

31. ODENHOLT, I.; HOLM, S.E. \& CARS, O. - Effects of supra and sub-MIC benzylpenicillin concentrations on group A $\beta$-haemolytic streptococci during the postantibiotic phase in vivo. J. Antimicrob. Chemother., 26: 193-201, 1990.

32. ODENHOLT-TORNQVIST, I. \& BENGTSSON, S. - Postantibiotic effect, and postantibiotic effect of subinhibitory concentrations of sparfloxacin on Gram-negative bacteria. Chemotherapy, 40: 30-36, 1994.

33. OLIVEIRA, I.C.M.; DE MATTOS, M.C.; AREAL, M.F.T. et al. - Pulsed-field electrophoresis of human group B streptococci isolated in Brazil. J. Chemother., 17: 258-263, 2005.

34. OLIVEIRA, I.C.M.; DE MATTOS, M.C.; PINTO, T.A. et al. - Genetic relatedness between group B streptococci originating from bovine mastitis and a human group B streptococcus type $\mathrm{V}$ cluster displaying an identical pulsed-field gel electrophoresis pattern. Clin. Microbiol. Infect., 12: 887-893, 2006.

35. RAMADAN, M.A.; TAWFIK, A.F.; SHIBL, A.M. \& GEMMELL, C.G. - Post-antibiotic effect of azithromycin and erythromycin on streptococcal susceptibility to phagocytosis. Antimicrob. Agents Chemother., 42: 362-366, 1995.

36. REED, W.P.; SELINGER, D.S.; ALBRIGHT, E.L.; ABDIN, Z.H. \& WILLIAMS Jr., R.C - Streptococcal adherence to pharyngeal cells of children with acute rheumatic fever. J. infect. Dis., 142: 803-810, 1980.

37. SHIBL, A.M. - Effect of antibiotics on adherence of microorganisms to epithelial cell surfaces. Rev. infect. Dis., 7: 51-65, 1985

38. SPELLERBERG, B. - Pathogenesis of neonatal Streptococcus agalactiae infections. Microbes Infect., 2: 1733-1742, 2000.

39. TEIXEIRA, L.A.; FIGUEIREIDO, A.M.S.; FERREIRA, B.T. et al. - Sialic acid content and surface hydrophobicity of group B streptococci. Epidem. Infect., 110: 87-94, 1993.

40. TOMASZ, A. - From penicillin-binding proteins to the lysis and death of bacteria: a 1979 view. Rev. infect. Dis., 1: 434-467, 1979.

41. TYLEWSKA, S.; HJERTÉN, S. \& WADSTRÖM, T. - Effect of subinhibitory concentrations of antibiotics on the adhesion of Streptococcus pyogenes to pharyngeal epithelial cells. Antimicrob. Agents Chemother., 20: 563-566, 1981.

Received: 29 October 2007

Accepted: 25 June 2008 